\section{Algunas consideraciones sobre la fotografía a través de la cosmovisión de Jorge Luis Borges}

Alejandra Niedermaier ${ }^{(*)}$

${ }^{(*)}$ Fotógrafa, investigadora y docente de la carrera de Diseño de Imagen y Sonido en la Universidad de Palermo y en la Escuela de Fotografía Motivarte.

Resumen: A medida que uno se introduce en el mundo de Jorge Luis Borges va descubriendo distintas formas de percibir, de empaparse de toda esa particular cosmovisión que su obra trasmite. Su pensamiento circular, sus signos laberínticos, sus repetidas obsesiones provocan tratar de extenderlas a la fotografía, a tratar de establecer ciertas relaciones, ciertos vínculos con ese lenguaje que, desde sus inicios, acompaña los derroteros de la vida humana, de la que justamente Borges se ocupó en sus textos.

La fotografía es un medio poético de revelaciones y asombros que se encuentran invocados y convocados en sus textos provocando una intensa reciprocidad entre lo visual y lo verbal.

Palabras claves: retratos - simulacro - intertextualidad - climas - espacio - tiempo - memoria - hallazgos.

[Resúmenes en inglés y portugués en la página 62]

\title{
Introducción
}

A medida que uno se introduce en el mundo de Jorge Luis Borges va descubriendo distintas formas de percibir, de empaparse de toda esa particular cosmovisión que su obra trasmite. Su pensamiento circular, sus signos laberínticos, sus repetidas obsesiones provocan tratar de extenderlas a la fotografía, tratar de establecer ciertas relaciones, ciertos vínculos con ese lenguaje que, desde sus inicios, acompaña los derroteros de la vida humana, de la que justamente Borges se ocupó en sus textos. Así es como surgen cuatro exploraciones que finalmente se unen para tratar de completar ese entramado. En primer lugar, el análisis y la historia de los retratos que ilustran aspectos de su vida y de su personalidad. Luego, actuaciones directas de Jorge Luis en torno a la fotografía. En tercer lugar, el relato de los fenómenos de intertextualidad que sus textos han suscitado en distintos fotógrafos argentinos, a través de trasposiciones cuyo caudal de sentido nos introduce, al mismo tiempo, en la obra fotográfica de cada uno y en la obra literaria. Y, una vez dentro de su literatura, abrir sus textos y relacionarlos estéticamente con algunas variables que la fotografía ontológicamente contiene.

\section{Duplicados}

"Qué raro que toda persona tenga pequeños duplicados de sí misma. Son como los repuestos de sí que tenía en la tumba el faraón"

Jorge Luis Borges en el Recuerdo de Adolfo Bioy Casares. ${ }^{1}$ 
Jorge Luis compara así los retratos fotográficos con los tempranos antecedentes de la función social de este género como la memoria funeraria egipcia, las estelas griegas y las inscripciones en los sarcófagos romanos. Los egipcios creían que si se perennizaba la apariencia del rey, éste continuaría existiendo para siempre. Para ello, ordenaban a los escultores a labrar el retrato del monarca en granito y lo colocaban en la tumba donde, en realidad, nadie podía verlo. La intención era que este relieve operara de hechizo y ayudase a su alma a revivir a través de la imagen. El escultor recibía el nombre de "el que mantiene la vida". La necesidad de retratarse existe desde la Antigüedad, sin embargo, es durante el siglo XIX que surge con gran intensidad una fuerte necesidad de individuación, de contemplarse a sí mismo y de que los hijos pudiesen conservar esa imagen para siempre. Este reconocimiento del deseo de representación, de signo, de lenguaje y por ende de comunicación es absolutamente trasladable a la aparición de la fotografía.

Tanto la ciencia como el arte demandaban una nueva forma de representación, una representación metonímica y no mediatizada. Según Deleuze y Guattari, de algún modo el deseo nace de la intersección de la necesidad y la demanda. Las necesidades derivan muchas veces del propio deseo.

Es por eso que, luego de extensas e intensas búsquedas ópticas y químicas en diversos puntos del universo, el 19 de agosto de 1839 la fotografía encuentra su patente en París y se la introduce en el mundo durante una sesión conjunta de las Academias de Ciencias y de Artes con el nombre de daguerrotipo. A esas búsquedas alquímicas se refiere Jorge Luis en este fragmento:

El alquimista piensa en las secretas

leyes que unen planetas y metales

y mientras cree tocar enardecido

el oro aquél que matará la Muerte.

Dios, que sabe de alquimia, lo convierte

en polvo, en nadie, en nada y en olvido. ${ }^{2}$

La fotografía evita la nada y el polvo, asegura cierta inmanencia justamente gracias a la alquimia.

El retrato siempre navega entre dos esferas: la pública y la privada; y nos aporta un panorama que es también una mirada sobre la sociedad. Asimismo nos habla del "ojo de la época" ${ }^{3}$. La descripción de las siguientes imágenes justifica este concepto:

Retratos de Fanny Haslam de Borges (1842-1935), abuela paterna de Jorge Luis, nos muestran un rostro decidido. Ella hospedó a muchas de las sesenta y cinco maestras procedentes de Norteamérica convocadas por Domingo Faustino Sarmiento que se distribuyeron en distintos puntos de nuestro país para ejercer un importante rol docente. Borges hace referencia a ella en varios poemas:

Por Frances Haslam, que pidió perdón a sus hijos

por morir tan despacio,

por los minutos que preceden al sueño,

por el sueño y la muerte,

esos dos tesoros ocultos,

por los íntimos dones que no enumero,

por la música, misteriosa forma del tiempo. ${ }^{4}$

Ha soñado a mi abuela Frances Haslam en la guarnición de Junín,

a un trecho de las lanzas del desierto,

leyendo su Biblia y su Dickens. ${ }^{5}$ 
Este lenguaje productor y difusor de sentido conlleva una búsqueda de representación. Es por eso que, en sus inicios, acudir a un estudio para ser retratado implicaba justamente esas exploraciones a las que se acaba de hacer referencia en los párrafos anteriores.

Su abuela materna, Leonor Suárez Haedo de Acevedo (1837-1918), visitó el estudio de B. Loudet quien le hizo un retrato frontal con bordes ovalados esfumados (modo muy propio de la época) y que también muestra una mirada firme.

Bartolomé Loudet (1823-1887) era un químico oriundo de Toulouse, Francia, que arribó a la Argentina en 1855, desempeñándose como ayudante del Estudio Fotográfico de Emilio Lahore. En 1861 instaló su propio estudio en la calle De la Piedad (hoy Bartolomé Mitre) 344 con el nombre de Galería San Miguel. Su ayudante era Alejandro Witcomb quien fundaría años más tarde el famoso estudio Witcomb Mackern y que retratara a Leonor Acevedo de Borges (1876-1975), madre de Jorge Luis, a los dos años. Alejandro Witcomb (1835-1905), de origen inglés, le compró a Christiano Junior su estudio de la calle Florida, destacándose como retratista. Luego, sus hijos y otros convierten el estudio en uno de los más prestigiosos con sucursales en Rosario y Mar del Plata. A partir de 1896, se agregó al estudio una galería de arte que contaba con un amplio programa de exposiciones. El mencionado estudio fue el responsable de la fotografía oficial de los presidentes de la Argentina hasta 1960. Las fotografías producidas por el estudio han originado una importante colección.

Por su parte, Christiano Junior retrató a Leonor de bebé en brazos de su madre. José Christiano de Freitas Henriques Junior (1832-1902) llegó a Buenos Aires proveniente de Brasil en 1867. Tenía un importante estudio en la calle Florida. Retrató a Domingo F. Sarmiento con la banda presidencial y a políticos como Lucio V. Mansilla, Adolfo Alsina y Luis Sáenz Peña. Era el fotógrafo oficial de la Sociedad Rural Argentina cuando ésta realizó su primer exposición en 1875. Además de su trayectoria como retratista, elaboró un gran "Álbum de vistas y costumbres de la República Argentina."

El estudio Chutte \& Brooks retrató a Leonor a los seis años. Charles Wallace Chutte y su socio Thomas Brooks se desempeñaban como fotógrafos retratistas en Buenos Aires y en Montevideo con estudios en ambas ciudades.

Una vez más, la historia de la fotografía se encuentra estrechamente vinculada con la historia sociopolítico-cultural de un país.

Una encantadora foto del ámbito privado muestra a Jorge Luis a los diez años y a Norah, su hermana, a los ocho años en Montevideo vestidos ambos de marineritos. Norah se convierte en los siguientes años en una importante pintora con un trazo y una pincelada de especiales características.

Tomada por los hermanos Forero es la emblemática foto de los integrantes de la revista Sur en momentos de su fundación en 1931, en donde se encuentran posando en los peldaños de una escalera. $\mathrm{Al}$ respecto, Victoria Ocampo manifestó: "Quise inmortalizar el nacimiento de la revista SUR. Llamaron a los hermanos Forero que hacían esas fotos a domicilio, con ese magnesio que cegaba. Tomaron varias poses. Elegí tres, que son las que siempre se publican." En esas fotos, además de la presencia de Jorge Luis, encontramos también a Norah entre los colaboradores de la revista y editorial.

En el género del retrato es importante detectar las aperturas de significación que se han producido en ese viaje de ida y vuelta que se establece entre la retratística inicial y la práctica contemporánea.

El retrato siempre incluye una dilemática y binaria situación entre el yo y el otro, el observador y el observado.

En París, Victoria Ocampo conoció en la librería que dirigía Adrienne Monnier a la fotógrafa Gisèle Freund (1912-2000). Gisèle estudió sociología en la universidad de Freiburg, Alemania. Comenzó a tomar fotografías cuando su padre, coleccionista de arte, le regaló a los quince años una cámara 
Leica. Su actividad fotográfica empezó a sistematizarse un $1^{\circ}$ de mayo de 1932 en Frankfurt durante una manifestación (la última que se realiza en el período de la República de Weimar ya que en la misma se registran incidentes con grupos nazis). Se doctoró en La Sorbone con una tesis titulada "La fotografía en Francia del siglo XIX", texto que amplíaría luego para publicar su libro La fotografía como documento social. Por el nazismo, tomó la ciudadanía francesa en 1940.

A partir de allí comenzó a realizar una serie de retratos de distintos escritores. Entre muchos otros, retrató a Walter Benjamin, el autor de los primeros ensayos sobre fotografía. Gisèle fotografió, asimismo, a Virginia Woolf a instancias de Victoria. En 1942, Victoria la invitó a la Argentina. Gisèle efectúó una de las más hermosas imágenes que se conocen de ella. A escondidas de Victoria, realizó unas muy logradas tomas de Eva Duarte y de Juan Domingo Perón entre los años 1943 y 1944 mientras se desempeñaba en la Argentina para la agencia France Libre. Ese mismo año, retrató también a Jorge Luis Borges en una imagen muy fresca donde él aparece sentado en el banco de un parque.

Se presume que Gisèle es también la autora del fotomontaje conocido como "Biorges". Se trata de un tríptico compuesto por un retrato de Borges, otro de Adolfo Bioy Casares y una tercera imagen que es una superposición de ambos retratos. Este fotomontaje, técnica que siempre contiene la figura retórica de la metáfora, muestra visualmente la estrecha amistad que existía entre ambos escritores. Borges fue retratado reiteradas veces por distintos fotógrafos nacionales e internacionales en diversos escenarios. No es el propósito de la presente investigación enumerar todos ni hacer una minuciosa descripción de cada uno. Sí adentrarse en algunos que trasmiten especialmente la esencia del retratado y en otros que revelan su íntima relación con los libros.

Lisl Steiner (1927), fotógrafa que vivió en la Argentina durante veintisiete años para instalarse luego en New York, fotografió a distintas personalidades. Volvió a la Argentina con frecuencia y, en el año 1979, visitó Buenos Aires a propósito de una exposición de sus imágenes que se realizó en el Museo de Arte Moderno. Durante ese viaje, y a pedido de la revista Time, retrató a Jorge Luis en su departamento y relató en una nota aparecida en Convicción el 5 de junio:

"Me llevo también las lágrimas de Borges. He estado esta mañana en su casa, he obtenido de él algunas fotos y me ha pedido que le leyera un poema de Heinrich Heine, en alemán por supuesto. No le ha importado que lo viera llorar. Sus ojos eran aún más tristes.”

Lisl recuerda cabalmente el momento que describe la nota. Rememora que se dirigió tres días seguidos al departamento de Jorge Luis en horas de la mañana para cumplir con el encargo de la revista y que el poema por ella leído, que le causara tanta emoción, se llamaba "La batalla de Hastings". ${ }^{6} \mathrm{El}$ primer día, Lisl le relató acerca de su proyecto denominado "Niños de las Américas", una serie de fotografías de chicos de toda la región, para el que le solicita un texto o una frase, recibiendo una rotunda negativa. Al segundo día, ella insistió nuevamente y volvió a recibir una respuesta desalentadora; pero, al tercero, Borges la hizo sentarse con un anotador y lápiz en la mano para dictarle en inglés una frase para su proyecto. Ella le pidió que se la traduzca y él accedió instantáneamente: "No pasa un día sin que un niño descubra el mundo, como ya lo hizo Adán. Hagamos lo imposible para que sienta que está en el paraíso".

Aproximadamente en 1980, Jorge Luis fue fotografiado por Paola Agosti (1947) en una imagen en blanco y negro con un ángulo de toma picado en donde él aparece sentado en un sillón y se destaca un gato extremadamente blanco en una pose muy relajada. Nuestra mirada alterna entre uno y otro personaje gracias a una diagonal invisiblemente trazada. El otro punctum ${ }^{7}$ de la foto es el bastón 
apoyado en la pierna. En la foto que Julie Méndez Ezcurra (1949-1991) le saca tres años más tarde y que ella tituló Borges y Beppo, el gato blanco conserva su postura co-protagónica. En esta imagen, la luz que proviene de una ventana lateral ilumina toda la escena. En la pared del living del departamento de la calle Maipú, se aprecian distintos marcos pequeños pero, en el más grande y central, se vislumbra una pintura de Norah.

Estas dos fotografías transmiten un sentimiento especial de duración. Es como si ambas contuviesen lo vivido hasta el momento de la toma.

Diane Arbus (1923-1971) lo fotografió en un plano americano en el Central Park nevado.

Richard Avedon (1923-2004) conservó con él su costumbre de fondo claro, cámara de formato medio y rostro dirigido hacia el retratante.

Humberto Rivas (1937) realizó una seguidilla de primeros planos que transmiten cierta secuencialidad, donde uno puede imaginarse a Jorge Luis recitando alguno de sus poemas o comentando animadamente, tal vez, cómo Schopenhauer descifró el universo. ${ }^{8}$

Annemarie Heinrich (1912-2005) con su esmerado sistema de encuadre, iluminación y copiado logró en sus retratos, tomados en 1966, desde momentos de honda introspección y dramatismo hasta una sonrisa franca y abierta pocas veces vista en Borges.

Sara Facio (1932) lo retrató en reiteradas oportunidades entre 1960 y 1980 tanto en la Biblioteca Nacional como en su casa. Su foto más paradigmática es en la que él aparece arrodillado buscando un libro en un anaquel. El análisis de un aspecto formal de la imagen nos conduce directamente a su más hondo sentido; si la separamos en planos, veremos que en primer lugar percibiremos la biblioteca y, un poco más atrás, a Borges en estrecha relación con el mueble.

Es Alicia D’Amico (1933-2001) quien, en todas las tomas del año 1960, incluyó en la escena los aspectos significantes de la vida del modelo, es decir, que reflejó visualmente su esencial relación con los libros, con la escritura y con "las galerías de una biblioteca por las que anduvo Paul Groussac (...)”. ${ }^{9}$ Alicia plasmó así lo lúdico pero, a su vez, la solemnidad; mostró su desesperanza y al mismo tiempo su esperanza.

John Berger en su libro Aquí nos vemos realiza un recorrido por distintas ciudades y sitios. En su itinerario se detiene en Ginebra y comienza mencionando una fotografía de Borges tomada, posiblemente, a principios de los años ochenta, uno o dos años antes de dejar Buenos Aires para instalarse en la ciudad donde fallece. Berger percibe en esta imagen que la ceguera era como una prisión pero que al mismo tiempo,

(...) su cara era una cara habitada por muchas otras vidas. Es una cara bien acompañada; muchos otros hombres, muchas otras mujeres, con sus apetitos, hablan por sus ojos casi ciegos. Es una cara que expresa innumerables deseos; un retrato que se podría clasificar bajo el epígrafe 'Anónimo' y utilizarse para los poetas en general, los poetas de todos los tiempos.

En el retrato encontramos una mirada que nos conduce directamente hacia distintos aspectos de la persona retratada, una mirada dirigida a la búsqueda de plasmar una síntesis biográfica de la misma. Los fotógrafos mencionados, y los no mencionados, produjeron esos "duplicados" que le llamaban tanto la atención a Jorge Luis. Configuran ese otro que le posibilita preguntarse: 
¿Cuál de los dos escribe este poema

de un yo plural y de una sola sombra? ${ }^{10}$

Esta estrofa actúa, además, como una prueba de la indicialidad del lenguaje fotográfico.

\section{Sueltos fotográficos}

Al daguerrotipo se lo solía llamar "espejo con memoria". En Fervor de Buenos Aires, el primer libro de Jorge Luis (publicado en 1923 con una tirada de 300 ejemplares y con un grabado de Norah en la tapa representando la fachada de una casa con reja) menciona:

Los daguerrotipos mienten su falsa cercanía

de tiempo detenido en un espejo

y ante nuestro examen se pierden como fechas inútiles

de borrosos aniversarios. ${ }^{11}$

Referencias directas a la íntima relación que se puede establecer con el retrato de una persona amada o añorada las encontramos en distintos párrafos de El Aleph:

De nuevo aguardaría en el crepúsculo de la abarrotada salita, de nuevo estudiaría las circunstancias de sus muchos retratos, Beatriz Viterbo, de perfil, en colores; Beatriz, con antifaz, en los carnavales de 1921; la primera comunión de Beatriz; Beatriz, el día de su boda con Roberto Alessandri; Beatriz, poco después del divorcio, en un almuerzo del Club Hípico; Beatriz, en Quilmes, con Delia San Marco Porcel y Carlos Argentino; Beatriz, con el pekinés que le regaló Villegas Haedo; Beatriz, de frente y de tres cuartos, sonriendo; la mano en el mentón.

(...) En la calle Garay, la sirvienta me dijo que tuviera la bondad de esperar. El niño estaba, como siempre, en el sótano, revelando fotografías. Junto al jarrón sin una flor, en el piano inútil, sonreía (más intemporal que anacrónico) el gran retrato de Beatriz, en torpes colores. No podía vernos nadie; en una desesperación de ternura me aproximé al retrato y le dije: Beatriz, Beatriz Elena, Beatriz Elena Viterbo, Beatriz querida, Beatriz perdida para siempre, soy yo, soy Borges.

(...) Nuestra mente es porosa para el olvido; yo mismo estoy falseando y perdiendo, bajo la trágica erosión de los años, los rasgos de Beatriz.(...)

El lenguaje fotográfico participa de ambos mecanismos, tanto del recuerdo como del olvido. El uso de fotografías para comprender distintos sucesos históricos pasados o presentes permite la reconstrucción del encadenamiento de sus distintos antecedentes. La fotografía como huella de un suceso ocurrido adquiere un valor de testigo (el "yo estuve aquî" 12 del fotógrafo y de lo fotografiado) y, a su vez, de símbolo. Por otra parte, al evocar se activa una simultánea y extraña percepción del aquí y del allá, del entonces y del ahora.

Es entonces este medio el que a la vez configura la apreciación de tiempo y espacio y es capaz de captar cierto infinito borgeano que aparece en esta prosa. Existe una ligazón entre la concepción de que la fotografía se comporta como un "espejo" o como una "ventana" ${ }^{13}$ con lo que el narrador 
percibe en ese sótano, visiones de "todos los lugares del orbe, vistos desde todos los ángulos" y donde "vi todos los espejos del planeta". Subyace también una transformación en imágenes de una especie de memoria y conciencia mezclada con el encuentro con lo inesperado.

Para John Szarkowski, la fotografía-ventana es la que intenta captar la realidad, la que muestra los sucesos. La fotografía-espejo, en cambio, es una mirada hacia el yo del fotógrafo. Por otra parte, la imagen también puede comportarse simultáneamente como espejo y como ventana. Este par se apoya sobre el énfasis de las imágenes en la realidad pero, a su vez, sobre el énfasis en la idea. Ambas características habitan en la fotografía y las comparten, de algún modo, con El Aleph, produciendo una reciprocidad entre lo verbal y lo visual.

Horacio Coppola (1906), fotógrafo vinculado por su formación y por su obra a los comienzos de la modernidad del lenguaje fotográfico en la Argentina, ilustró en 1930 con imágenes de la ciudad el libro Evaristo Carriego de Jorge Luis Borges.

La exposición que Coppola realizara junto a Grete Stern (1904-1999) en 1935 marcó un punto de inflexión en la fotografía argentina. La muestra se llevó a cabo en la Editorial Sur. La nota que escribiera Jorge Romero Brest ${ }^{14}$ para la mencionada muestra en el número 13 de la revista Sur desmenuza, reflexiona e instala en el país una polémica sobre la ubicación de la fotografía dentro del arte, dándole categoría de "primera manifestación seria de arte fotográfico". Coppola realizó un relevamiento de la ciudad de Buenos Aires que fue plasmado en numerosos libros y revistas de la época. Sus registros, muchos de ellos encargos de la Municipalidad para el aniversario número cuatrocientos del nacimiento de la ciudad, se encuentran en una publicación denominada Buenos Aires 1936. Efectuó un relevamiento fotográfico y fílmico de la construcción del obelisco.

Borges mismo eligió las dos fotografías para el libro sobre Evaristo Carriego. Se trata de una toma en la calle Jean Jaurés y otra en la calle Paraguay a la altura del barrio de Palermo. Coppola y Borges solían caminar juntos la ciudad y, en una oportunidad, en el barrio mencionado, el primero registra con su cámara el reflejo de una casa en un charco. Borges definió "Esto es Buenos Aires". La toma fue así titulada.

Gustavo Thorlichen (1906-1986) realizó un libro de fotografías denominado Argentina que fue publicado alrededor del año 1958. La segunda edición a cargo de la Editorial Sudamericana, está escrita en tres idiomas: castellano, inglés y alemán, evidenciando que se trataba de un libro for export compaginado por el propio Thorlichen e impreso en Stuttgart, Alemania. Thorlichen agradece la ayuda recibida para la segunda y ampliada edición publicando además, en la solapa de cierre, algunos datos concretos sobre el país. Jorge Luis Borges escribe el prólogo del mismo.

En 1941, la Editorial Sur había publicado un libro denominado San Isidro que incluía un poema de Silvina Ocampo y fotos de Gustavo. Es posible que Thorlichen y Borges se conociesen en la editorial. En 1963, Victoria mencionaba a propósito de este libro: "El libro sobre San Isidro está agotado (...) espero poder hacer una segunda edición, que muchos me piden. La casa y árboles fotografiados en ese libro (o gran parte de ellos) ya no existen fuera del recuerdo."

Thorlichen llegó a nuestro país en la década del '30 procedente de Alemania. Alrededor de 1940 poseía su propio estudio en la calle Reconquista entre la Av. Corrientes y Sarmiento. En 1948 realizó una exposición de sus trabajos en la Galería Kraft.

En 1953, y durante una exposición en La Paz, Bolivia, Gustavo conoció al médico argentino Ernesto Guevara, quien entró en la galería donde estaba exhibiendo sus imágenes. El Che apuntó en su diario que lo impresionaba la manera de trabajar y la sencilla técnica que Thorlichen utilizaba para alcanzar excelentes composiciones. Tuvieron oportunidad de realizar juntos un recorrido por las montañas que rodean La Paz e indudablemente intercambiaron algunos secretos sobre técnica fotográfica. El 
Che se ganó la vida como fotógrafo ambulante en los parques y jardines de México y como periodista de una agencia argentina durante los Juegos Panamericanos de 1955 que se llevaron a cabo en Ciudad de México. ${ }^{15}$

Es interesante detenernos en el prólogo escrito por Jorge Luis. Comienza estableciendo un debate sobre el pictorialismo ${ }^{16}$. Este movimiento tenía como objetivo considerar la fotografía como una de las Bellas Artes. Su estética tendía a deformar la imagen real y el fotógrafo personalizaba su mirada. Borges dice al respecto:

“¿Cómo admitir una rivalidad o una alianza de la eterna pintura y de la advenediza fotografía, cómo suponer que una armazón furtiva y endeble, servil como un espejo y mimética como un mono, incapaz de omitir o de preferir, pudiera amenazar la supremacía del ojo humano, de la diestra humana y del ya legendario pincel de Apeles tanto más admirable cuanto más perdida su obra?”

El mismo advierte a continuación que su planteo "encubría una falacia". La paradoja es uno de los recursos a los que nuestro prologuista era afecto, especialmente por su capacidad de contrariar conceptos generalizados y de producir así un sentido nuevo. Borges hace referencia al debate que también se planteara el primer teórico de la fotografía, Walter Benjamin, sobre la pérdida de aura en la obra de reproducción técnica. La noción de aura, núcleo de las teorías benjamianas, descansa sobre un doble principio que constituye el juego del acto fotográfico: un principio de distancia y uno de proximidad. Este complejo concepto sirve para explicar, por un lado, un modo histórico de ser de la mirada y, por otro, una caracterización de los objetos de la naturaleza y los objetos artísticos. ${ }^{17}$ Es importante recordar, entonces, lo ya mencionado: la aparición de la fotografía se produce porque tanto la ciencia como el arte demandaban una nueva forma de representación, una representación metonímica y no mediada. De esta manera, la fotografía oscilaba ontológicamente entre el arte y la "técnica". ${ }^{18}$ En su paradoja, Borges no repara (o tal vez sí) en que justamente es la fotografía la que tiene la capacidad de "omitir o de preferir" en su inevitable gesto del encuadre, esa esencial elección de lo que incluimos o excluimos dentro de la imagen, lo que mostramos, lo que ocultamos.

Luego, apoyándose en Schopenhauer y en Bergson menciona que “ (...) quedará borrada la oposición de natural y artificial, de órgano y de instrumento."

En todas las cartas, diarios y escritos de las figuras próceres del nacimiento de este lenguaje: (Nicéphore Niepce, Jacques Louis Mandé Daguerre, Henry Fox Talbot, por mencionar solamente a los más conocidos, encontramos la preocupación por: "la copia de las visiones de la naturaleza" 19 , "la reproducción espontánea de las imágenes de la naturaleza proyectadas en la cámara oscura" ${ }^{20}$ y "la naturaleza pintada por sí misma". ${ }^{21}$

Es decir, en el imaginario de la época circulaba el deseo de representación de la naturaleza y de conciliar ésta misma con la cultura. La aparición de la fotografía era justamente un intento de aunar ambos conceptos, al "escribir con luz" por citar una definición ampliamente difundida. Talbot escribió en su diario el 3 de marzo de 1839 la frase "palabras de luz". Podemos arriesgar entonces que, desde sus comienzos, este lenguaje nace con la noción de textualidad en su interior. Continuando con este pensamiento de representación de la naturaleza, existe una estrecha relación entre naturaleza y arte; relación que nos lleva directamente al par original/copia, variables tan propias de la ontología de la fotografía que, como objeto de preocupación, tuvieron una presencia mucho mayor en el siglo XIX que en décadas posteriores. En torno a la textualidad, Borges reconoce "Quien abomina de la má- 
quina debería también abominar del cuerpo del hombre. Lo mismo habría que decir de aquel otro instrumento, el lenguaje."

Prosigue el prólogo diciendo que la Argentina presenta un sinfín de conflictos para ser retratada ya que, según él, es dificultoso obtener una correcta percepción de su vastedad (tanto la de las llanuras como la de Buenos Aires) y porque "lo pintoresco es la excepción en este país (...)" Tal vez sea por eso que, al finalizar, reconoce la capacidad de este fotógrafo de sintetizar todos los paisajes imaginarios propios de la nación, diciendo "(...) de ahí lo singular de la proeza que ha efectuado Thorlichen con lucidez, pasión y felicidad."

En el año 1986 el reconocido fotógrafo Henri Cartier Bresson (1908-2004) recibió el premio "Novecento" en la ciudad de Palermo en Italia. Jorge Luis Borges fue quien lo nominó para ese premio e incluso lo llegó a llamar para consultarle si lo iba a aceptar. Las características del galardón establecían que el ganador del anterior sería el que nominaba al siguiente. Henri le preguntó a Borges por qué lo había elegido a él y éste le contestó que era en reconocimiento a sus ojos y a su mirada en virtud de que él era ciego. Jorge Luis falleció antes de poder entregárselo, tarea que le encomendó a María Kodama. A Cartier Bresson le sorprendió gratamente que la ceremonia tuviese lugar en el mismo hotel donde sus padres habían pasado su luna de miel y lo habían concebido.

María Kodama es quien documentó los viajes que ambos realizaron por el mundo, conformando, de algún modo, un álbum de los últimos años de la vida de nuestro escritor. En estas tomas se puede apreciar a Borges en París, Roma, Madrid, Estambul, Venecia, Ginebra, Creta y ante pirámides egipcias. En el libro Atlas, que contiene fotos de María, él expresa:

Mi cuerpo físico puede estar en Lucerna, en Colorado o en el Cairo, pero al despertarme cada mañana, al retomar el hábito de ser Borges, emerjo invariablemente de un sueño que ocurre en Buenos Aires. ${ }^{22}$

\section{Fotógrafos que se inspiraron en Pierre Menard}

La intertextualidad es un fenómeno absolutamente interdisciplinario. Es un concepto que proviene de la semiótica del discurso expuesto por Julia Kristeva en los '60 y retomado por Umberto Eco y por Roland Barthes. Se trata de textos que circulan en red, que se encuentran conectados, relacionados entre sí y que siempre remiten a otros textos a través de citas, alusiones o reescrituras.

Jean Francois Lyotard señala a la posmodernidad como un proyecto de reescritura. Precisamente por eso, la intertextualidad se inscribe como una práctica de este tiempo.

Asimismo, encaja bien en las búsquedas contemporáneas globales por dos motivos: por un lado, llama a las competencias culturales del receptor y, por otro, tiene valor de impacto.

Eliseo Verón dice: "Si el libro, como la fotografía, tiene una particular importancia en nuestra modernidad, es porque la lectura, irremediablemente, es una aventura individual." ${ }^{23}$

El receptor tendrá la posibilidad entonces de aventurarse a decodificar a qué fenómeno intertextual hace referencia la trasposición, siempre poniendo en juego sus conocimientos culturales. Se trata entonces de un proceso de "alegorización" que remite a un tema transitado y que permanece en el imaginario, un imaginario culturalmente segmentado. Por otra parte, estará invitado tácitamente a dirigir una atenta mirada hacia el principio de construcción de la nueva imagen.

Cabe aclarar también que algunos teóricos denominan esta modalidad con vocablos tales como "cita", "remake" o "pastiche" (que procede de la música pero que se ha extendido a todas las disciplinas). 
Yo creo, sin embargo, que el término "trasposición" es el que mejor designa a esta modalidad que ha adquirido la categoría de un género por la cantidad de autores involucrados en todo el mundo. Se analizará en las próximas líneas, dentro del fenómeno de la intertextualidad, la práctica de la trasposición fotográfica en relación a distintos textos de Borges.

La trasposición designa la idea de traslado, de transplante, de poner algo en otro sitio, de apropiarse de ciertos modelos pero pensándolos, en este caso, en otro registro o en otro sistema, logrando, al mismo tiempo, inquietar el texto original. Probablemente, uno de sus atractivos sea la posibilidad de jugar con los paradigmas. En este sentido, posee efectivamente un carácter lúdico.

En muchas ocasiones, estamos ante una reapropiación de estilos. Para analizar esto, muchos teóricos toman, casi como mito de origen, la siguiente trasposición literaria: "Pierre Menard, autor de El Quijote". Jorge Luis Borges en su libro Ficciones cuenta la historia de este "escritor" que no intentó reescribir dicha obra. La ambición de Pierre Menard era directamente "escribirla". Se trata, como analiza Gerard Genette, ${ }^{24}$ de una transformación mínima porque en realidad es una imitación total, una búsqueda imaginaria de identificación.

Con Pierre Menard comenzamos a conocer un Borges conceptual ya que el deseo de Pierre es "pensar, analizar, inventar", es decir, asumir una mirada más distante, más objetivada, más apegada a la idea. El texto de Borges relatando la vida y la obra de Pierre Menard se inscribe también en la estética del simulacro. Subyace el deseo de apropiarse de un estilo admirado; el producto siempre tendrá una significación distinta, por provenir de personalidades diferentes y por realizarse en otra instancia de tiempo, cumpliendo así con cierta fantasía de desdoblamiento que también se observa en varios de sus poemas. Ambas características son adoptadas para varios de sus proyectos por el fotógrafo y teórico español Joan Fontcuberta (1955), gran admirador de Jorge Luis. Fontcuberta trabaja intensamente con el simulacro para demostrar que la fotografía no está tan ligada a la veracidad y que no es un reflejo "mimético" ${ }^{25}$ de la realidad, como se la considerara durante muchas décadas. Ha realizado un exhaustivo trabajo fotográfico disfrazado de estudio zoológico sobre la evolución de distintos animales prehistóricos. La exposición de este ensayo ${ }^{26}$ contaba con imágenes de restos de animales armados por taxidermistas como si se tratara de una especie extraña, con datos aparentemente científicos sobre el tema y con un exhaustivo detalle sobre la vida del zoólogo (fotos de él a diversas edades y en distintas situaciones). Sin embargo, todo era producto de una gran inventiva. Se puede decir que Fontcuberta es un creador de contextos, sus mecanismos de construcción de sentido apuntan a envolver directamente al receptor, haciéndose eco del siguiente pensamiento:

Temió que su hijo meditara en ese privilegio anormal y descubriera de algún modo su condición de mero simulacro. No ser un hombre, ser la proyección del sueño de otro hombre ¡qué humillación incomparable, qué vértigo! ${ }^{27}$

En el proyecto "Sputnik" (1997) Joan vuelve a ironizar en base a la concepción de que Fácilmente aceptamos la realidad, acaso porque intuimos que nada es real. ${ }^{28}$

Se trata de otro registro fotográfico, en este caso, sobre la vida de un astronauta. En este proyecto la sátira es fácilmente reconocible. Delacroix escribió que "en arte, todo es mentira" en una declaración que primaba su capacidad de invención sobre su función mimética y reproductora. Fontcuberta continúa entablando series donde realiza manifestaciones paródicas, al igual que su admirado Borges. Según Gerard Genette la pintura y la literatura son susceptibles de transformación por pertenecer a un régimen de inmanencia autográfico, es decir, contener un modo de existencia de una fase. Por este 
motivo, las fotografías que se analizarán a continuación se liberan del esquema institucionalizado de la trasposición, en virtud de que nacionalizan, individualizan y personalizan los temas a los que hacen referencia. Se emparentan, al mismo tiempo, con la siguiente poesía de Roberto Juarroz de 1987:

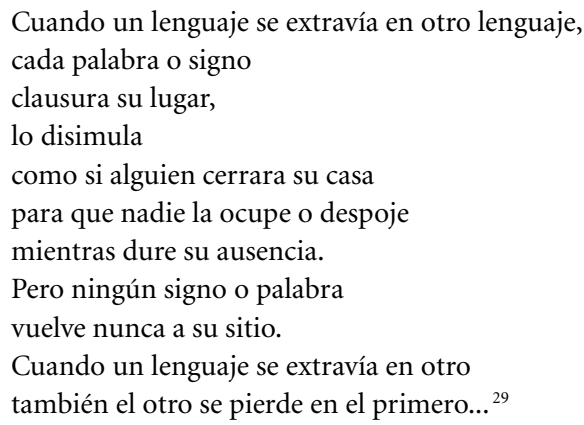

Convocados justamente por Joan Fontcuberta, en el año 1996, cuando éste se desempeñaba como director de los Encuentros Internacionales de Arles, ${ }^{30}$ los fotógrafos argentinos Res y Bibi Calderaro desarrollaron diferentes trabajos en base a textos de Jorge Luis Borges.

Bibi cuenta que recibió con mucha alegría el encargo de Joan y que se pasó un verano sentada frente a una ventana leyendo sus obras y tomando notas. Recuerda que le llamaron especialmente la atención el eterno retorno a distintos temas, la ambigüedad entre sueño y vigilia y la inclusión de animales. Tanto es así, que incluye una tortuga como protagonista de su audiovisual. Rememora que había leído una entrevista en la cual Borges mencionaba que de pequeño tomaba agua de un aljibe o de un pozo de patio donde vivía una tortuga, concluyendo, él, por lo tanto, que bebía agua de tortuga.

Bibi se propuso aunar los textos y los climas borgeanos con temas relacionados con las dictaduras argentinas, tocando tangencialmente el tema de los secuestros y jugando con la similitud de las palabras tortuga/tortura. Trabajó fotografiando escenas de películas (entre las que se encuentra la escena de un secuestro, por ejemplo) e intercalándolas con otras fotos. Sus tomas fueron directas y en color. Se trató de una proyección con una narración acentuada por la elección del sonido.

A mi pregunta sobre si continúa trabajando en estos fenómenos intertextuales, respondió que suele usar textos varios para sus videos y performance pero no en base a un autor determinado.

Res (1957), por su parte, también realizó un audiovisual. Se trata de setenta imágenes en blanco y negro basadas en una versión muy personal del significado que tenían los sueños para Jorge Luis. El eje del relato es La esfera de Pascal aunque reconoce la influencia de textos tales como El Aleph, Elegía de los portones y Funes, el memorioso. Colaboraron a desentrañar los textos Noe Jitrik y Palo Pandolfo. Res eligió como escenario de sus imágenes el Río de la Plata, la antigua facultad de Filosofía y Letras y la antigua sede de la Biblioteca Nacional (Borges fue su director) así como otras locaciones referidas en sus relatos. A cada uno de estos escenarios le antepuso una esfera de una boleadora manufacturada en el siglo XIX por aborígenes de la llanura pampeana. Se puede reconocer que esta serie de imágenes también hace alusión a La biblioteca de Babel, donde se puede leer:

"La Biblioteca es una esfera cuyo centro cabal es cualquier hexágono, cuya circunferencia es inaccesible". La elección de Res de utilizar un elemento que tuviera una relación tan fuerte con la argentinidad, corresponde, tal vez, al deseo de apropiarse de los sueños y de la figura de Jorge Luis, de volverlos 
absolutamente locales y de quitarles esa internacionalidad que tanto él como sus textos gozan.

En una de las setenta imágenes, Res parte de uno de los retratos de Alicia D’Amico mencionados unos cuantos párrafos más arriba. Se trata de la foto donde Borges se encuentra en un pasillo de la biblioteca con todos los estantes repletos de libros detrás. En la imagen de Res, en lugar del escritor, aparece desenfocada la esfera y las repisas se encuentran vacías.

Como si esos despojados anaqueles dijeran:

Creo en el alba oir un atareado

rumor de multitudes que se alejan;

son lo que me ha querido y olvidado;

espacio y tiempo y Borges ya me dejan. ${ }^{31}$

Eduardo Grossman (1946) recibió en el año del centenario del nacimiento de Borges la propuesta de la revista Viva de trabajar fotográficamente sus textos. Tras una lectura de varios poemas y prosas cortas, Eduardo concluyó que el elemento más borgeano para plasmar las propiedades de su discurso era la utilización de espejos. Recuerda que los espejos tuvieron el efecto de transformar las diferentes tomas, haciendo aparecer mágicamente los inquietantes poderes que nuestro autor les adjudicaba.

Uno de mis insistidos ruegos a Dios y al ángel de mi guarda

era el de no soñar con espejos.

Yo sé que los vigilaba con inquietud.

Temí, unas veces, que empezaran a divergir de la realidad;

otras, ver desfigurado en ellos mi rostro por adversidades extrañas. ${ }^{32}$

Para Eduardo, las trece imágenes realizadas en película diapositiva color con cámara de formato medio son "un ejercicio visual" reconociendo, de esta manera, que los fenómenos de trasposición de literatura a fotografía contienen un desafío importante.

Las locaciones de las mismas tienen directa relación con los poemas: Colonia de Sacramento; la ex Biblioteca Nacional; la casa en Adrogué donde Borges viviera; los cementerios de la Recoleta y Chacarita; Parque Lezama y la esquina de Chile y Tacuarí, domicilio de Estela Canto. ${ }^{33}$

La anteriormente mencionada revista publicó en agosto de 1999 una selección de esta serie.

Grossman es autor también de un conjunto de fotografías dedicadas a distintos textos de Roberto Arlt, a modo de homenaje ya que se trata de su escritor argentino favorito. El entramado de sentido de estas fotografías no solamente responde a las fantasías, sueños y delirios de los distintos personajes que habitan las novelas de Arlt, sino que se despegan de su proceso intertextual para adquirir un clima absolutamente propio y conformar un corpus de una tensión dramática muy contundente.

Facundo de Zuviría (1954) fue también convocado para los diferentes homenajes que aparecieron alrededor del centenario del nacimiento del escritor que nos ocupa. Reconoció de inmediato su fascinación por la obra de Borges, en especial, por todo lo atinente a Buenos Aires y a lo criollo. Tal vez sea por eso que participó de proyectos que pusieron especial énfasis en los sitios de esta ciudad nombrados en sus textos y que fueran significativos en su vida. Se trató de imágenes para un libro denominado Revelaciones y para una exhibición/libro del Centro de Cultura Contemporánea de Barcelona que se llamó Cosmópolis. Facundo relata su preferencia por la obra ficcional: El Sur, El hombre de la esquina Rosada y Emma Zunz, entre otros. Hace hincapié en un párrafo de El Sur, cuan- 
do Dahlman a bordo del tren ve que el vagón se ha transfigurado, cruzado por sombras y cuando al salir de la ciudad dice que la misma "se desgranaba en suburbios". Su libro de poesías favorito es Fervor de Buenos Aires.

Su elección del blanco y negro tenía por objeto quitarle toda referencia temporal. Buscaba cierto dramatismo en las sombras y un ángulo que asegurara su relación con los textos. En esos momentos, leía y releía su obra. Su obsesión era poder alinear la mirada de Borges con la suya.

Las fotografías que realizara para el Tributo a Borges (exposición itinerante y catálogo que organizara Patricio Lóizaga) nos dan la sensación de estar ante ciertos objetos íntimos y fetiche. Se trata de imágenes de manuscritos de Jorge Luis, en una de ellas, combina la toma de un original con la conocida foto de él con su madre (donde Leonor aparece apoyada en la balaustrada de un puente).

Facundo señala como uno de sus retratos favoritos el realizado por Pepe Fernández, donde se lo observa de pie, en ángulo picado sobre una rosa de los vientos, porque responde a la imagen de argentino universal y se emparenta con las ruinas circulares y los laberintos.

Ante mi consulta sobre si le interesaba la práctica intertextual para futuros proyectos, respondió que le gustaría trabajar en un proyecto compartido con un escritor, en el que haya una interacción entre ambos lenguajes, en virtud de la carga poética que ambos contienen.

Julio Fuks (1971) realizó entre los años 2003 y 2006 una serie denominada "El blanco más doctrinario", nombre emparentado a escritos de Osvaldo Lamborghini. Considera este trabajo fotográfico "en diálogo con la literatura". Surgió por un interés personal en relación con la poética en general y con la gauchesca en particular. En este sentido, Julio parte de conceptos literarios que son producto de una investigación previa. Luego, éstos "devienen en forma". En el proceso de visualización de las imágenes, él considera que las mismas "deben apuntar a una sintonía poética concreta". Destaca que lo importante es dejar de lado lo superficial para buscar lo medular en cada párrafo. Los textos inspiradores de Borges fueron $\mathrm{El}$ sur y $\mathrm{El}$ fin pero también hay influencia de textos de Lamborghini y de Miguel Briante. Además, registra ciertos intereses deleuzianos en cuanto al concepto de la orilla, donde no hay borde ni centro.

Las tomas son realizadas en blanco y negro y tienen directa relación con las obsesiones de Jorge Luis acerca de los cuchilleros. Las imágenes hablan de la afrenta, del duelo, de la espera y de la posible revancha. Los personajes no tienen rostro (esculturas realizadas por Julio en alambre), sino la emulación del gesto y visualmente la figura se mezcla con su fondo (pasto, campo). El elemento icónico del cuchillo se destaca en todas las imágenes.
El cuchillo. La cara se ha borrado
$\mathrm{Y}$ de aquel mercenario cuyo austero
oficio era el coraje, no ha quedado
más que una sombra y un fulgor de acero. ${ }^{34}$

En varias de las milongas escritas por Borges a pedido de Carlos Guastavino se celebran las hazañas de cuchilleros famosos como Juan Muraña y Jacinto Chiclana, entre otros. Una de ellas es la Milonga de dos hermanos.

Julio no posee proyectos intertextuales inmediatos pero reconoce estar interesado en trabajar sobre Antonio Di Benedetto ya que es uno de sus autores predilectos. Le resulta muy atractivo el retrato mencionado en el primer apartado que Richard Avedon le hiciera al escritor motivo de estas líneas. Estos trabajos implican, evidentemente, dos exploraciones: por un lado, adentrarse en el proceso 
intelectual del autor de los textos sobre los que se basaron, en este caso, sobre Borges; $y$, por otro, introducirse en los propios procedimientos de pensamiento, de asociación y en sus propios mecanismos de construcción de sentido. Reaparece así el tema del estilo, ya no se trata de una sutil diferencia entre reproducción o repetición: en este caso, el modo del fotógrafo se trasunta voluntaria e involuntariamente en virtud de la búsqueda que realiza por encontrar sus propias poéticas para visualizar cualquier texto elegido, condenándolo a mostrar las trazas de su gesto y de sus obsesiones.

\section{Laberintos de espacio y de tiempo}

A continuación, una exploración hermenéutica para tratar de metaforizar ${ }^{35}$ sobre algunas variables de la fotografía a través del acompañamiento de pensamientos y poesías de Borges.

La fotografía congela la imagen en términos de espacio y de tiempo. Para Imannuel Kant, la estructura espacio/tiempo se conforma en el pensamiento humano para relacionarse con el mundo.

El tiempo es la sustancia de que estoy hecho. El tiempo es un río que me arrebata, pero yo soy el río; es un tigre que me destroza, pero yo soy el tigre; es un fuego que me consume, pero yo soy el fuego. El mundo, desgraciadamente, es real; yo, desgraciadamente, soy Borges. ${ }^{36}$

El gesto de obturar convierte simbólicamente al instante fotográfico en eternidad y es como un acto de apropiación de todos los instantes. Este acto de apropiación implica la posibilidad de repetir la vivencia del suceso a través de la observación de la fotografía.

"basta una sola 'repetición' para demostrar que el tiempo es una falacia..." ${ }^{37}$

Y esta experiencia puede producir:

Esos recuerdos no eran simples, cada imagen visual estaba ligada a sensaciones musculares, térmicas, etcétera. ${ }^{38}$

Así, estas variables de espacio y de tiempo, atributos inherentes a este lenguaje, se convierten en componentes de la memoria.

¿Cómo se sitúa la imagen foto entre el tiempo, la memoria, el olvido y la eternidad?

Leemos en el Timeo de Platón que el tiempo es una imagen móvil de la eternidad, y ello es apenas un acorde que a ninguno distrae de la convicción de que la eternidad es una imagen hecha con sustancias de tiempo. ${ }^{39}$

En este sentido, el poeta Federico García Lorca en un reconocimiento de que la fotografía, entre otras especificidades, es un medio para inventariar lo acontecido, incorporó a su proyecto teatral La Barraca (cuyo accionar se extendió desde 1931 a 1936 aproximadamente) a un fotógrafo cuyo nombre era Gonzalo Menéndez Pidal (1911). Gracias a sus tomas, Pidal pudo tornar en imperecedero lo perecedero. Por otra parte, este lenguaje desarrolla una memoria que nos ayuda a elaborar una nueva mirada sobre el devenir. Y es aquí donde surge la melancolía de Roland Barthes ${ }^{40}$ acerca del medio al mencionar en sus textos "esto ha sido". Borges dice al respecto: 


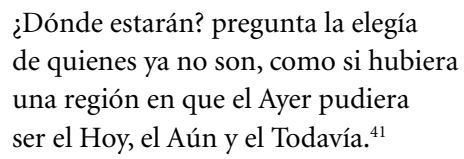

Una fotografía preserva un instante del tiempo y favorece su almacenamiento en la memoria, se convierte en el registro de algo que en el momento de su observación está ausente. La fuerza constativa de la foto existe justamente porque se refiere al tiempo y no al objeto.

Teóricos como Walter Benjamin ${ }^{42}$ o como John Berger ${ }^{43}$ hacen alusión a la particularidad de la fotografía de contener al mismo tiempo pasado y futuro al recortar simplemente el presente, en virtud de que la labor de la memoria anula el tiempo. La conmoción surge, también, por la discontinuidad. Ante una fotografía se reconfigura lo sucedido, los mecanismos de la memoria se ponen en marcha.

Más allá del azar y de la muerte

duran y cada cual tiene su historia, pero todo esto ocurre en esa suerte de cuarta dimensión, que es la memoria. ${ }^{44}$

A pesar de que, a veces, no sea lo deseado:

Borraré la acumulación del pasado.

Haré polvo la historia, polvo el polvo.

Estoy mirando el último poniente.

Oigo el último pájaro.

Lego la nada a nadie. ${ }^{45}$

Y de la memoria y el olvido enlazamos con otra obsesión de Jorge Luis, los espejos:

Sólo una cosa no hay. Es el olvido.

Dios, que salva el metal, salva la escoria

y cifra en Su profética memoria

las lunas que serán y las que han sido.

Ya todo está. Los miles de reflejos

que entre los dos crepúsculos del día

tu rostro fue dejando en los espejos. ${ }^{46}$

Según Jacques Lacan, el espejo funciona como umbral, como lugar de articulación entre lo imaginario y lo simbólico.

Podemos hablar de una estrecha relación entre la imagen especular y la imagen fotográfica. Ambas invitan a detener la mirada. Experiencias indiciales (donde se perciben las trazas del fenómeno que las emitió) como el espejo, la foto y la sombra aseguran la existencia del objeto.

Sin embargo, tanto el azogue como los haluros de plata (incluso los pixeles) nos deparan una confrontación entre lo real y lo ideal. Ambos (azogue y haluro) contribuyen a tener más de una visión. Por otra parte, las imágenes producidas mediante espejos ofrecen una serie de particularidades que 
merecen nuestra atención. Entre ellas,

"Los espejos y la cópula son abominables porque multiplican el número de los hombres" ${ }^{47}$

De esta manera, Borges retorna al concepto de los duplicados fotográficos mencionados al comienzo de este recorrido, donde la palabra "reproductibilidad", que aquí aparece implícitamente, en el lenguaje fotográfico se realiza de modo explícito.

Duane Michals, fotógrafo nacido en Pennsylvania en 1932, utiliza con frecuencia el espejo en sus imágenes, especialmente en sus series "Las cosas son raras" (1973) y "El espejo de Alicia" (1974) donde logra narraciones visuales cuyos climas se encuentran en consonancia con los que habitan en los textos de Jorge Luis. Duane expresa lo siguiente: ${ }^{48}$

"Antes que cualquier otra cosa amo la imaginación, amo escribir, amo a los escritores. Me gusta Borges, es mi escritor favorito, me gustan William Blake y Lewis Caroll, me gusta la gente que se inventa el universo con su imaginación." Y agrega: "En vez de fotografiar el momento decisivo, yo me veo llevado a fotografiar el momento anterior y el siguiente." ${ }^{49}$

Es probable que la utilización de espejos le posibilite este juego poético.

Por otra parte, se podría aventurar que en las numerosas fotos de desdoblamiento de Duane también se halla presente la impronta de su autor favorito. Ambos, escritor y fotógrafo utilizan con frecuencia esta modalidad. Es por ello que se podría partir de la consideración de la paradoja de que el acto de ver y mirar detenidamente en búsqueda de una profundización (de eso se trata la fotografía) se despliega al abrirse en dos.

¿Hasta dónde los fotógrafos nos perdemos en el objeto fotografiado? ¿Cuánto del otro, cuánto de nosotros, qué extraña interrelación se entabla entre ambos? El tema de reconocerse, de perderse en el otro yo de nuestro objeto de creación, aparece muy profundamente indagado en Borges y yo, especialmente en el siguiente fragmento:

Por lo demás, yo estoy destinado a perderme, definitivamente, y sólo algún instante de mi podrá sobrevivir en el otro.

Como en el cuento de Julio Cortázar sobre el axolott ${ }^{50}$, ¿cuándo dejamos de narrar para ser narrados? Por otra parte, esta frase también nos puede resonar familiar:

(...) pero me reconozco menos en sus libros que en muchos otros $(. . .)^{51}$

En ocasiones, ¿no nos reconocemos más en las fotos admiradas de un colega que en nuestro propio trabajo?

Francois Recanati dice que el signo posee un carácter doble: puede ser opaco y transparente, puede descubrir pero también ocultar la cosa significada, es decir, resulta una especie de paradoja. Esto que se evidencia claramente en los textos de Borges sucede también con muchas imágenes fotográficas cuya lectura no resulta tan transparente.

Tal vez la solución de esta paradoja consiste en aceptar un tercer estado del signo: transparente y opaco a la vez, es decir, un signo que se refleja de un modo pero que, al mismo tiempo, representa algo dis- 
tinto de sí. Un signo que responde a las características que describe Umberto Eco en Obra Abierta:

La apertura de un texto es la condición de todo goce estético. Toda forma susceptible de goce, en cuanto dotada de valor estético, es 'abierta'. La ambigüedad de los signos no puede separarse de su organización estética, sino que por el contrario, los dos valores le sostienen y se motivan el uno al otro.

El pensamiento circular, el volver siempre a un mismo tema, maquillado para no ser reconocido, disfrazado con el mismo fin, pero a la vez sutilmente identificable. Esto que se encuentra en los textos de Jorge Luis, se encuentra también como preocupación, como temática, en las diferentes búsquedas que plasman los fotógrafos en sus distintos proyectos. Sin embargo, se puede entrever claramente que las obsesiones son siempre las mismas y que ese lenguaje poroso y dúctil que es la fotografía los acompaña. La fotografía es una apropiación simbólica de nuestros pequeños y grandes universos.

Una frase de Rainer Maria Rilke, poeta que le gustaba a la fotógrafa Grete Stern (1904-1999) ${ }^{52}$, describe cabalmente el entramado circular al que se hace referencia: "La búsqueda es una, aunque se refracte en distintos temas". Este es también el espíritu de la siguiente frase de Borges que la autora de estas líneas difunde en sus cursos y charlas acerca de los componentes del retrato y del autorretrato:

Un hombre se propone la tarea de dibujar el mundo. A lo largo de los años, puebla con imágenes de provincias, de reinos, de montañas, de bahías, de naves, de islas, de peces, de habitaciones, de instrumentos, de astros, de caballos y de personas. Poco antes de morir, descubre que ese paciente laberinto de líneas traza la imagen de su cara. ${ }^{53}$

Se ha tratado de reflexionar así sobre este lenguaje flexible y permeable que en la contemporaneidad contiene varios registros que funcionan "a la vez" y que, además, no pertenece a un espacio cultural único, es decir, que desde diversas instancias, presenta un sistema semántico en permanente movimiento. La fotografía comprendida entonces como un medio poético de exploración, interrogación, revelación y desnudamiento. También de imaginación, de sueños, hallazgos y asombros tan invocados y convocados en los textos de Jorge Luis Borges.

\section{Notas}

1 Prólogo de Borges Fotografía y Manuscritos, Miguel de Torre Borges (recop), 1987 Bs.As., Ediciones Renglón.

2 Jorge Luis Borges, Fragmento del Poema El alquimista.

3 Michael Baxandall, "El ojo de la época”, en Pintura y vida cotidiana en el Renacimiento Italiano, 1978 Barcelona, Gustavo Gili.

4 Jorge Luis Borges, Fragmento del Poema Otro poema de los dones.

5 Jorge Luis Borges, Fragmento del Poema Alguien sueña.

6 En su escrito del 15 de junio de 1986, María Esther Vázquez hace referencia a este poema en Nestor Montenegro, Borges por el siglo de los siglos, 1999, Buenos Aires, Ediciones Simurg, pp 105/6.

7 Término acuñado por Roland Barthes para describir los elementos que habitan en una foto que nos llaman la atención, que colocan un acento en la imagen y que invitan a la lectura del resto de la misma.

8 Mencionado en Otro poema de los dones.

9 Nestor Montenegro, Borges por el siglo de los siglos, 1999 Buenos Aires, Ediciones Simurg.

10 Fragmento del Poema de los dones. 
11 Fragmento del poema Sala vacía, Fervor de Buenos Aires.

12 Se hace referencia aquí a la inscripción que Jan Van Eyck (1390-1441) introduce en su pintura "El matrimonio Arnolfini",1434 (National Gallery).

13 John Szarkowski, texto Mirrors and windows acompañante de la exposición organizada por él en el MOMA en 1978.

14 Jorge Romero Brest era una de las figuras más influyentes en la formación de la crítica de arte en América Latina. Publica libros y artículos sobre arte argentino, latinoamericano, europeo y norteamericano. Dicta cientos de conferencias y dirige el Centro de Artes Visuales del Instituto Torcuato Di Tella, centro de promoción de la experimentación artística de vanguardia.

15 Se conocen fotografías tomadas por Ernesto Guevara en un período que abarca desde 1951 hasta 1966, aproximadamente. Las fotografías en muchos casos acompañan sus diarios ya que viajaba siempre con una cámara incluso en los períodos de guerrilla.

16 Corriente fotográfica característica de fines de siglo XIX cuyos principales exponentes fueron Julia Margaret Cameron, Henry Peach Robinson y Robert Demachy.

17 Un modo casi laberíntico de aproximación, la sensación de estar cerca y lejos al mismo tiempo. Ambos (Benjamin y Borges) se encontraban seducidos por los laberintos y los utilizaban recurrentemente como metáfora.

18 Se utiliza este término en alusión al escrito de Walter Benjamin: "La obra de arte en la era de la reproducción técnica" en donde se efectúa un análisis de las razones de la aparición de la fotografía.

19 Nicephore Niepce.

20 Jacques Louis Mandé Daguerre.

21 Henry Fox Talbot.

22 Fragmento de El sueño en El Atlas.

23 Esto no es un libro, 2000 Barcelona, Editorial Gedisa, pág. 27.

24 Palimpsestos, la literatura en segundo grado, 1989 Madrid, Editorial Taurus.

25 Mencionado unas líneas más arriba por JLB en el prólogo al libro de fotografías de Gustavo Thorlichen.

26 La primer exposición de este proyecto se realizó en un museo de ciencias naturales.

27 Fragmento de Las ruinas circulares.

28 Fragmento de El inmortal.

29 Roberto Juarroz, Poesía vertical, 1993 Buenos Aires, Emecé

30 Todos los veranos en la localidad de Arles, Francia, se desarrollan desde hace 38 años estos Encuentros Internacionales de Fotografía. La dirección del Encuentro está a cargo de una personalidad diferente en cada edición.

31 Fragmento de Límites.

32 Fragmento de "Los espejos velados", El hacedor.

33 Joven de la que JLB se enamoró y a la que le dedicó en 1949 su cuento El Aleph, regalándole además el manuscrito.

34 Fragmento de Alusión a una sombra/Muerte de mil ochocientos noventa y tantos.

35 Aristóteles decía que metaforizar bien es percibir lo semejante (Poética).

36 Fragmento de Otras Inquisiciones, Nueva refutación del tiempo.

37 Fragmento de El milagro secreto.

38 Fragmento de Funes el memorioso.

39 Fragmento de Historia de la eternidad.

40 La cámara lúcida, 1982 Barcelona, Gustavo Gili.

41 Fragmento de El Tango.

42 El concepto al que se alude no sólo aparece en Pequeña historia de la fotografía, sino también en Infancia en Berlín hacia 1900 y en Crónica de Berlín.

43 Mirar, Ed. 2005 Buenos Aires, Ediciones de la Flor. 
44 Fragmento de Adrogué.

45 Fragmento de El suicida

46 Fragmento de Everness

47 Tlön, Uqbar, Orbis Tertius

48 Revista Exit, El Espejo, número cero, Año 2000

49 De algún modo, vuelve hacerse referencia aquí a la caracterización efectuada por John Szarkowski, nombrada unas páginas atrás.

50 Cuento Axolotl en Final del Juego.

51 Fragmentos de Borges y yo en El hacedor donde JLB combina prosa y poesía.

52 Su retrato a Jorge Luis ha sido señalado por Facundo de Zuviría como otro de sus favoritos.

53 Fragmento del epílogo del libro El hacedor.

\section{Referencias Bibliográficas}

Alifano, Roberto. (1988). Borges, biografía verbal, Barcelona: Plaza \& Janés Editores. Benjamin, Walter. (1973). Pequeña historia de la fotografía, Madrid: Taurus.

Berger, John. (2006). Aquí nos vemos, Buenos Aires: Alfaguara, pág. 57.

Bonet, Juan Manuel. (2006). “Horacio Coppola: los ojos del siglo”, Diario La Nación, 23 de julio.

(2005). Coppola, Buenos Aires, libro-catálogo de la Galería Jorge Mara - La Ruche.

Borges, Jorge Luis. (2003). Antología poética 1923-1977, Madrid: Alianza Editorial.

(2000). Ficciones. Buenos Aires: Emecé.

(1997). El hacedor, Madrid: Alianza Editorial.

(1978 ). Historia de la eternidad, Madrid: Alianza Editorial.

(1974). Obras completas, Buenos Aires: Emecé.

Catálogo de la muestra fotográfica itinerante Tributo a Borges que se realizó en el año 1999 organizada por la Revista Cultura/Patricio Lóizaga

Catálogo del Centro Cultural Borges correspondiente a la exposición realizada en julio/agosto de 1996 denominada Norah Borges, casi un siglo de pintura.

De Torre Borges, Miguel. (1987). (recop) Borges Fotografía y Manuscritos, Buenos Aires: Ediciones Renglón.

Eco, Umberto. (1985). Obra Abierta, Barcelona: Planeta Agostini.

Fontcuberta, Joan. (1998). El beso de judas, Barcelona: Ed. Gustavo Gili.

Genette, Gerard. (1989). Palimpsestos, la literatura en segundo grado, Madrid: Editorial Taurus.

Goldstein, Gabriela. (2005). La experiencia estética, Buenos Aires: Del Estante Libros.

Gómez, Juan. (1986). La fotografía en la Argentina, 1840/1889, Buenos Aires: Abadía Editora.

Didi Huberman, Georges. (2006). Ante el tiempo, Buenos Aires: Adriana Hidalgo Editora.

Juarroz, Roberto. (1993). Poesía vertical, Buenos Aires: Emecé.

Montenegro, Nestor. (1999). Borges por el siglo de los siglos, Buenos Aires: Ediciones Simurg.

Niedermaier, Alejandra. (2008). La mujer y la fotografía: una imagen espejada de autoconstrucción y construcción de la historia, Buenos Aires: Editorial Leviatán.

(2007). Desde la docencia y la investigación fotográfica: la trasposición, su devenir/su límite, en AA.VV, Actas de Diseño 3, II Encuentro Latinoamericano de Diseño, Comunicaciones Académicas, Universidad de Palermo, Bs.As. - pp. 180-185.

(2006). Distintos caminos en el abordaje de la historia de la fotografía, en AA.VV. Terceras Jornadas de Historia del Arte, Universidad Adolfo Ibáñez, Valparaíso, Chile, pp. 193-199.

Oliveras, Elena. (2004). Estética, la cuestión del arte, Buenos Aires: Ariel Filosofía. 
Recanati, Francois. (1981). La transparencia y la enunciación, Buenos Aires: Editorial Hachette.

Revista del Fotoclub Argentino. (1998). Nro. 74, septiembre/noviembre.

Revista Exit. (2000). El Espejo. Nro. cero.

Rey, Pedro B. (2004). "Henri Cartier Bresson: la danza del instante”, Diario La Nación, 8 de agosto.

Sarlo, Beatriz. (1995). Borges, un escritor en las orillas, Buenos Aires, Ariel.

Sontag, Susan. (2007). Bajo el signo de Saturno, Buenos Aires: De Bolsillo.

Speranza, Graciela. (2006). Fuera de campo, literatura y arte argentinos después de Duchamp, Barcelona: Editorial Anagrama, pp. 91-121.

Suplemento Zona, Diario Clarín. (2001). 21 de enero.

Thorlichen, Gustavo. (1958). Argentina, Stuttgart, ca. Editorial Sudamericana - Prólogo Jorge Luis Borges.

Verón, Eliseo. (2000). Esto no es un libro, Barcelona: Editorial Gedisa.

\section{Agradecimientos}

Lisl Steiner

Mari Loup Sougez

Alicia Sanguinetti

Leticia Sahagun

Patricia Viaña

Bibi Calderaro

Julio Fuks

Eduardo Grossman

Res

Facundo de Zuviría

Summary: As we enter the world of Jorge Luis Borges we discover different ways of perceive, of be soaked in all his particular worldview that his work conveys. His circular thought, his labyrinthine signs, his repeated obsessions provoke to try to extend them to photography, to try to establish certain relations, certain bonds with that language that, from its beginnings, accompanies the map courses of human life, of that exactly Borges took care in his texts. Photography is a means of poetic revelations and amazement that are invoked and called in their texts causing intense reciprocity between the visual and the verbal.

Keywords: climates - findings - intertextuality - memory - pictures - simulacrum - space - time.

Resumo: À medida que um se introduz no mundo de Jorge Luis Borges vai descobrindo diferentes formas de perceber, de empapar-se de toda essa particular cosmovisión que sua obra transmite. Seu pensamento circular, seus signos laberínticos, suas repetidas obsessoes provocam tratar de estendê-las à fotografia, a tratar de estabelecer certas relaçoes, certos vínculos com essa linguagem que, desde seus inícios, acompanha os derroteros da vida humana, da que justamente Borges se ocupou em seus textos. A fotografia é un meio poético de relevaçoes e asombros que se encontram invocados e convocados em seus textos provocando uma intensa reciprocidade entre o visual e o verbal.

Palavras chave: achados - climas - espaço - intertualidade - memoria - simulacro - retratos - tempo. 